\title{
Acetylcholine produces contractions mediated by the cyclooxygenase pathway in arterial vessels in the Chilean frog (Calyptocephalella gayi)
}

\author{
F. A. Moraga ${ }^{*}$ and N. Urriola-Urriola ${ }^{a}$ \\ ${ }^{a}$ Laboratorio de Fisiología, Hipoxia y Función Vascular, Departamento de Ciencias Biomédicas, Facultad de Medicina, \\ Universidad Católica del Norte, Coquimbo, Chile \\ *e-mail: fmoraga@ucn.cl
}

Received: January 11, 2016 - Accepted: June 15, 2016 - Distributed: November 31, 2017

(With 2 figures)

\begin{abstract}
Previous studies performed in marine fish (I. conceptionis and G. laevifrons) showed that indomethacin blocked arterial contraction mediated by acetylcholine (ACh). The objective of this study was to determine if contraction induced by acetylcholine is mediated by the cyclooxygenase pathway in several arterial vessels in the Chilean frog Calyptocephalella gayi. Arteries from the pulmonary (PA), dorsal (DA), mesenteric (MA) and iliac (IA) regions were dissected from 6 adult specimens, and isometric tension studies were done using dose response curves (DRC) for ACh $\left(10^{-13}\right.$ to $\left.10^{-3} \mathrm{M}\right)$ in presence of a muscarinic antagonist (Atropine $10^{-5} \mathrm{M}$ ) and an unspecific inhibitor of cyclooxygenases (Indomethacin, $10^{-5} \mathrm{M}$ ). All the studied arteries exhibited vasoconstriction mediated by ACh. This vasoconstriction was abolished in the presence of atropine in DA, MA and IA and attenuated in PA. Indomethacin abolished the vasoconstriction in MA and attenuated the response in PA, DA and IA. Similar to marine fish, C. gayi have an ACh-mediated vasoconstrictor pattern regulated by muscarinic receptors that activate a cyclooxygenase contraction pathway. These results suggest that the maintenance in vasoconstrictor mechanisms mediated by $\mathrm{ACh} \rightarrow \mathrm{COX} \rightarrow$ vasoconstriction is conserved from fish to frogs.
\end{abstract}

Keywords: frog, vascular reactivity, acetylcholine, atropine, indomethacin, cyclooxygenase.

\section{Acetilcolina produz contrações mediadas pela via da ciclooxigenase em vasos arteriais da rã chileno (Calyptocephalella gayi)}

\section{Resumo}

Estudos feitos em peixes marinhos (I. conceptionis e G. laevifrons) têm demostrado que a indometacina bloqueia a contração arterial mediada por acetilcolina (ACh). O objetivo do presente estudo foi avaliar o efeito da via da ciclooxigenase na contração induzida por ACh em vasos arteriais da rã chilena Calyptocephalella gayi. Foram dissecadas regiões das artérias pulmonares (PA), dorsal (DA), mesentérica (MA) e ilíaca (IA) de seis espécimes adultos e realizados estudos de tensão isométrica utilizando curvas dose-resposta (CDR) de ACh $\left(10^{-13}\right.$ a $\left.10^{-3} \mathrm{M}\right)$ na presença de um antagonista muscarínico (atropina, $10^{-5} \mathrm{M}$ ) e um inibidor das ciclooxigenases (indometacina, $10^{-5} \mathrm{M}$ ). Todas as artérias evidenciaram uma resposta vasoconstritora mediada por ACh. Esta resposta vasoconstrictora foi suprimida na presença de atropina nas artérias DA, MA, IA e atenuada na PA. A indometacina suprimiu a vasoconstrição na artéria MA e atenuou a resposta nas artérias PA, DA e IA. Tal como os peixes marinhos, a C. gayi tem um padrão de vasoconstrição mediado por Ach que é regulado pelos receptores muscarínicos e pela ciclooxigenase. Estes resultados sugerem a conservação dos mecanismos vasoconstrictores mediados por $\mathrm{ACh} \rightarrow \mathrm{COX}$ em peixes e rãs.

Palavras-chave: rã, reatividade vascular, acetilcolina, atropina, indometacina, ciclooxigenase.

\section{Introduction}

Unlike mammalian arteries, acetylcholine does not cause endothelium-dependent relaxations in fish, our laboratory (Furchgott and Zawadzki, 1980; Miller and Vanhoutte, 1986; Olson and Villa, 1991) and corroborated in several vessels such as the dorsal, mesenteric, afferent and efferent branchial arteries in G. laevifrons and I. conceptionis indicated the presence of two muscarinic receptors of high and low sensitivity to acetylcholine supporting a

contraction mechanism related to muscarinic receptors (Moraga and Urriola-Urriola, 2014, 2015). In addition, our studies showed that ACh-mediated vasoconstriction was coupled to the ACh-COX contraction pathway previously described in fish (Moraga and Urriola-Urriola, 2014, 2015). This was similar to that reported in human and rat hypertension models (Vanhoutte et al., 2005; Shi et al., 2008) where there was an endothelium dysfunction because 
of a lower bioavailability of NO due to the increase in oxidative stress that stimulates COX and production of prostaglandin vasoconstrictors (Vanhoutte, 2011). Therefore, we propose that ectotherm animals such as amphibians could have a similar pattern of vascular response as that described in fish.

Amphibians and others derived from ancient tetrapods (who estimate that appear 385-365 million years ago (Clack, 2007). In general, amphibians have simple skeletons with significantly less bone than other modern vertebrates and their fishlike ancestors (Roček, 2003). Paleontology evidence suggest that Calyptocephalellidae present lineages of neobatrachians in being a species-poor lineage with a relictual distribution, they might be remnants of an ancient neobatrachian radiation that predated the breakup of Gondwana such as been proposed by Gomez et al. (2011), supporting idea an ancient species. In Chile, it is possible to find a very large species of frog named Calyptocephalella gayi [Anura, Calyptocephalellidae, helmeted water frog], that was originally known as Caudiverbera caudiverbera (Myers \& Stothers, 2006) until Vidal and Labra (2008) renamed it Calyptocephalella gayi. By other way, this species belongs to the endemic Calyptocephalellidae family represented by two genders: C. gayi and Telmatobufo C. gayi is a large sized amphibian with males reaching $120 \mathrm{~mm}$ and females $320 \mathrm{~mm}$ (snout - anus). This frog has a robust body, a large head with a short, round snout, small eyes in relation to the head, and irregularly stained smooth greenish skin with a white or yellowish belly. Their normal weight is about $0.5 \mathrm{~kg}$ but specimens weighing $3 \mathrm{Kg}$ have been found (Duellman, 2003). Currently, this species is only distributed in the central valley in Chile from Coquimbo (29 54'28'S and $71^{\circ} 15^{\prime} 15^{\prime}$ 'W) to Puerto Montt (41 $28^{\circ} 00^{\prime}$ 'S and $\left.72^{\circ} 56^{\prime} 00^{\prime \prime} \mathrm{W}\right)$ at altitudes from sea level to 1200 meters above sea level. They normally inhabit lakes, streams, and ponds that have soft shores with small slopes and abundant aquatic vegetation. These frogs feed on crustaceans, fish, little rodents and other amphibians (Cei, 1962) and are also considered delicacies themselves being cultivated on certified farms and sold as food.

With all, our objective was to evaluate the role of the acetylcholine-COX pathway by blockade with muscarinic antagonist (Atropine) and blockade with an unspecific inhibitor of cyclooxygenases (Indomethacin) in the arterial vessel of dorsal, mesenteric, pulmonary and iliac arteries in C. gayi.

\section{Material and Methods}

\subsection{Animals}

Six adult Calyptocephalella gayi were purchased from a farmer in Doñihue (34¹4'00'S and 7058'00'W), VI Region, Chile. All specimens were carried to the laboratory at the Universidad Católica del Norte and maintained for 5-7 days in filtered recirculation containers with fresh water at $15^{\circ} \mathrm{C}$. Afterward, corporal mass $(550 \pm 25 \mathrm{~g})$ and longitude snout-anus $(20 \pm 2 \mathrm{~cm})$ were measured for each specimen. Prior to experimentation, each specimen was anaesthetized in the transport container by the addition of benzocaine (1:1000) and subsequently killed by decapitation.

\subsection{Bath organ physiology}

Arterial vessels were carefully dissected from the following areas (Figure 1): Pulmonary (PA), dorsal (DA), mesenteric (MA) and iliac (IA) and were placed in cold $\left(4^{\circ} \mathrm{C}\right)$ physiological saline solution (PSS). The PSS contained (in $\mathrm{g} / \mathrm{L}$ ): balanced salt solution $[6.4 \mathrm{NaCl}, 0.03 \mathrm{KCl}$, $0.035 \mathrm{NaHCO} 3,1$ glucose, and $0.02 \mathrm{CaCl} 2 \cdot 2 \mathrm{H} 2 \mathrm{O}$, $\mathrm{pH}$ 7.2]. Individual arterial ring segments of $2 \mathrm{~mm}$ length were mounted in a four channel small vessel wire myograph (model 610M Danish Myotech, Denmark). The vessels were threaded onto two tungsten wires of $40 \mu \mathrm{m}$ in diameter and attached to a force transducer and a micrometer for isometric measurements. All signals were acquired by a system acquisition (Powerlab 8sp, ADInstrument, Australia) and the data collected on a personal computer for further analysis. After mounting the rings, the arterial segments were incubated in PSS at $25^{\circ} \mathrm{C}$ and gassed with air for $30 \mathrm{~min}$. Each vessel segment was stretched to its optimal diameter, i.e. the diameter at which it developed a contraction response to $\mathrm{PSS}-\mathrm{K}^{+},\left(\mathrm{PSS}-\mathrm{K}^{+}\right.$solution, $\mathrm{NaCl}$ was replaced by an equimolar amount of $\mathrm{KCl}$ ) using a diameter-tension protocol as previously described for mammalian small arteries (Stassen et al., 1997). In this way, the myograph permitted direct measurement of vessel wall tension while the internal diameter was controlled.

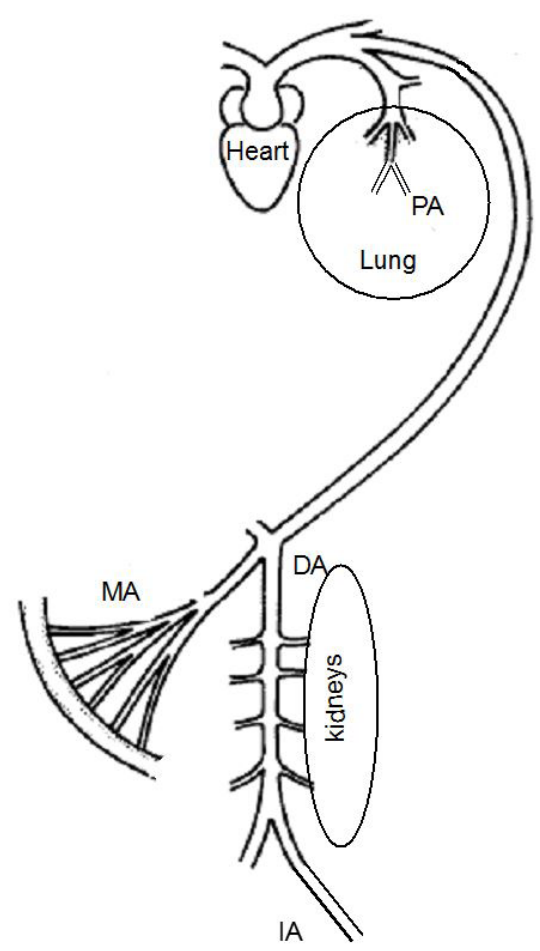

Figure 1. Schematic representation of circulation territories in Calyptocephalella.gayi isolated for the vascular studies. Where, PA (Pulmonary artery), DA (Dorsal artery); MA (Mesenteric artery) and IA (Iliac artery). 
Following an equilibration period of at least $30 \mathrm{~min}$, doses response curves (DRC) were performed for $\mathrm{KCl}$ (5.6-125 mM) and the cholinergic agonist acetylcholine (ACh) at concentrations ranging from $10^{-13}$ at $10^{-3} \mathrm{~mol} / \mathrm{L}$. Afterward, DRC for ACh were performed in vessels pre-incubated for 30 min with Atropine (At, $10^{-5} \mathrm{M}$ ), an muscarinic receptor antagonist, and indomethacin (IND, $10^{-5} \mathrm{M}$ ), an unspecific inhibitor of cyclooxygenases. Between experiments, the arterial preparations were allowed to recover for at least 30-60 min to return to resting basal tension.

All chemicals were reagent grade and purchased from Sigma Chemical (St Louis, MO, USA). The following drugs used in the study: ACh, at and IND were also purchased from Sigma Chemical (St Louis, MO, USA).

\subsection{Data analysis and statistics}

DRC were analyzed in terms of maximal response $(\mathrm{Rmax})$, and sensitivity $\left(\mathrm{EC}_{50}\right.$ or $\left.\mathrm{pEC}_{50}\right)$ to different contractile agents by fitting the individual data with a nonlinear sigmoid regression curve (Prism 4.0, Graphpad, San Diego, CA, USA). Rmax was expressed as (N/m). Sensitivity was expressed as $\mathrm{EC}_{50}$ (the concentration of agonist at which $50 \%$ of Rmax was obtained) or as $\mathrm{pEC}_{50}$ $\left(-\log \mathrm{EC}_{50}\right)$.

All results were expressed as mean \pm SEM. A two way ANOVA for repeated measurements was used for statistical analysis of physiological variables. Differences were considered significant when $p<0.05$ (Primer of Biostatistical v 3.0, Mc Graw Hill).

\section{Results}

The calculated internal diameter for all arteries is shown in Table 1. The optimal diameter determined for each arterial segment from the vascular territories revealed that DA was larger than PA, MA and IA, and MA and IA were larger than PA.

Responses to potassium chloride $(\mathrm{KCl})$. Table 2 summarizes the $\mathrm{EC}_{50}$ and Rmax parameters obtained from the analysis of the arterial response curves. No differences were observed in the $\mathrm{EC}_{50}$ response in any of the arteries evaluated. In contrast, Rmax increased significantly in the PA and MA when compared to those obtained from DA and IA.

Responses to acetylcholine. $\mathrm{pEC}_{50}$ and Rmax parameters obtained from the analysis of the arterial response curves in presence of $\mathrm{ACh}$ revealed that the sensitivity $\left(\mathrm{EC}_{50}\right)$ and Rmax were greater in PA as compared to DA, MA and IA $(p<0.05)$. Furthermore, no differences in sensitivity were observed between the DA, MA and IA. Also, a lower Rmax was observed in MA compared to DA and IA $(\mathrm{p}<0.05)$ (Table 2).

Response blockade with Atropine. In order to evaluate if the arterial contraction observed in the presence of ACh was blocked with At $\left(10^{-5} \mathrm{M}\right)$, DRC for ACh were performed in all arterial vessels. Furthermore, contractions induced by ACh were abolished in the presence of At in DA, MA and IA, and attenuated in PA (Figure 2, Table 2).

Response blockade with IND. In order to evaluate the mechanism of contraction induced by ACh, we blocked with IND $\left(10^{-5} \mathrm{M}\right)$ and DRC for ACh were performed

Table 1. Optimal diameter $(\mu \mathrm{m})$ in arterial vessels of Calyptocephalella gayi.

\begin{tabular}{cccc}
\hline PA & DA & MA & IA \\
\hline $345 \pm 51^{*}$ & $833 \pm 71^{\dagger}$ & $608 \pm 67$ & $657 \pm 45$ \\
$(6)$ & $(6)$ & $(6)$ & $(6)$ \\
\hline
\end{tabular}

Values represent an optimal diameter $(\mu \mathrm{m})$ and were expressed as mean \pm S.E.M. (n). *PA vs DA, MA, IA; †DA vs MA and IA. $(\mathrm{P}<0.05)$. Abbreviations: Pulmonary artery (PA); Dorsal artery (DA); Mesenteric artery (MA) and Iliac artery (IA).

Table 2. Summary of the parameter obtained of dose response curve of several treatments in four different vascular beds of Calyptocephalella gayi.

\begin{tabular}{|c|c|c|c|c|}
\hline & PA & DA & MA & IA \\
\hline \multicolumn{5}{|l|}{ CCR-K ${ }^{+}$} \\
\hline $\mathrm{EC}_{50}(\mathrm{mM})$ & $12.8 \pm 2.3$ & $14.9 \pm 2.3$ & $16,4 \pm 2,6$ & $18,2 \pm 1,8$ \\
\hline $\operatorname{Rmax}(\mathrm{N} / \mathrm{m})$ & $2.14 \pm 0.09$ & $1.47 \pm 0.03 * *$ & $2.18 \pm 0.04$ & $1.56 \pm 0.04 * *$ \\
\hline \multicolumn{5}{|l|}{ CCR-ACh } \\
\hline $\mathrm{pEC}_{50}(\mathrm{mM})$ & $-9.314 \pm 0.160 *$ & $-6.585 \pm 0.120^{\dagger}$ & $-7.424 \pm 0.350$ & $-6.971 \pm 0.113$ \\
\hline $\operatorname{Rmax}(\mathrm{N} / \mathrm{m})$ & $4.645 \pm 0.09 *$ & $1.462 \pm 0.084$ & $0.897 \pm 0.09^{\dagger \dagger}$ & $1.864 \pm 0.229$ \\
\hline \multicolumn{5}{|l|}{ CCR-Atrop } \\
\hline $\mathrm{pEC}_{50}(\mathrm{mM})$ & $-5.885 \pm 0.085^{*}$ & $0 \pm 0$ & $0 \pm 0$ & $0 \pm 0$ \\
\hline $\operatorname{Rmax}(\mathrm{N} / \mathrm{m})$ & $0.677 \pm 0.049 *$ & $0 \pm 0$ & $0 \pm 0$ & $0 \pm 0$ \\
\hline \multicolumn{5}{|l|}{ CCR-INDO } \\
\hline $\mathrm{pEC}_{50}(\mathrm{mM})$ & $-6.990 \pm 0.035 *$ & $-5.800 \pm 0.125$ & $0 \pm 0$ & $-6.536 \pm 0.07$ \\
\hline $\operatorname{Rmax}(\mathrm{N} / \mathrm{m})$ & $1.329 \pm 0.014^{*}$ & $0.300 \pm 0.015$ & $0 \pm 0$ & $0.372 \pm 0.016$ \\
\hline
\end{tabular}

Abbreviations: Pulmonary artery (PA); Dorsal artery (DA); Mesenteric artery (MA) and Iliac artery (IA). Mean \pm S.E.M. *PA vs DA, MA and IA; **DA and IA vs PA and MA; $\uparrow$ DA vs PA, MA and IA; $\dagger \dagger$ MA vs DA and IA $(\mathrm{P}<0.05)$. 
Dorsal

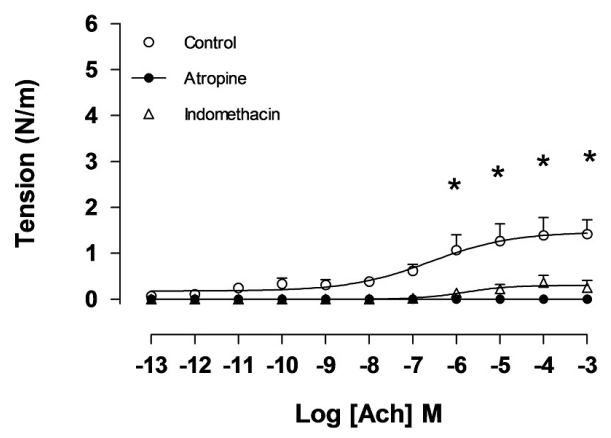

Mesenteric

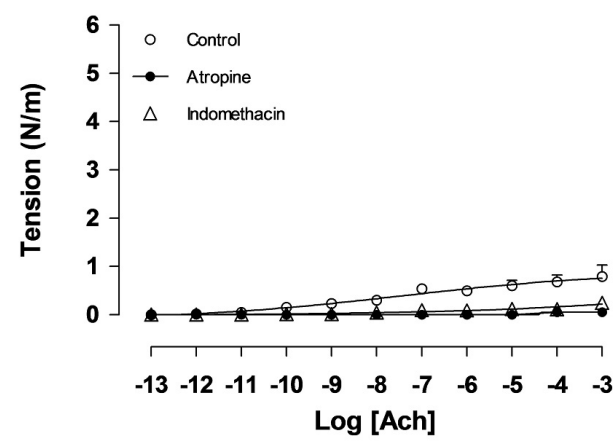

Pulmonar

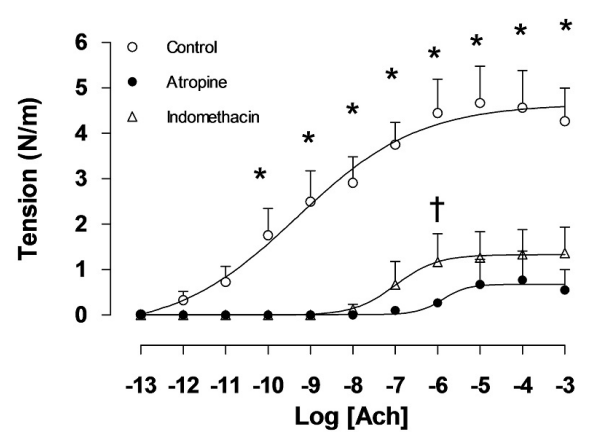

Iliac

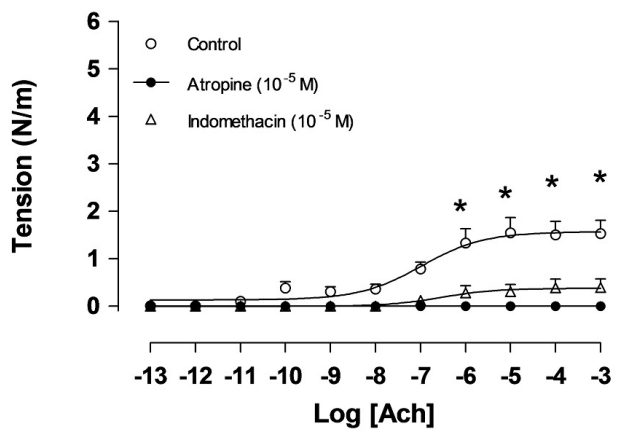

Figure 2. Acetylcholine dose-response curves of isolated rings from: Pulmonary artery (PA), Dorsal artery (DA); Mesenteric artery (MA) and Iliac artery (IA). Open circle (control), closed circle (Atropine, $10^{-5} \mathrm{M}$ ), open triangle (Indomethacin, $10^{-5} \mathrm{M}$ ). Each point represents the mean \pm S.E.M. Control vs Atropine and Indomethacin $\left({ }^{*} \mathrm{p}<0.05\right)$ and Atropine vs Indomethacin $(\dagger \mathrm{p}<0.05)$.

in all arterial vessels. Contraction induced by ACh was abolished only in MA in the presence of IND. In contrast, attenuated response was observed in PA, DA and IA (Figure 2, Table 2).

\section{Discussion}

Our study demonstrates that C. gayi possesses a vasoconstrictor mechanism mediated by $\mathrm{ACh} \rightarrow$ muscarinic receptor $\rightarrow$ cyclooxygenase pathway, similar to that previously described in marine fish (Moraga and Urriola-Urriola 2014, 2015).

\subsection{Vascular response to acetylcholine}

Our results show that all vessels studied (PA, DA, MA and IA) exhibited vasoconstriction mediated by ACh. The vasoconstriction observed in C. gayi suggests the presence of one muscarinic receptors present in PA, in contrast with described in marine fish. Briefly, the response described in marine fish was characterized by a high sensitivity to a range of $10^{-10}$ to $10^{-8} \mathrm{M}$ of ACh. A high sensitivity response to ACh was previously described in arterial rings from dorsal, afferent and efferent branchial, and mesenteric in isometric studies that was partially blocked by atropine $\left(10^{-5} \mathrm{M}\right)$. In this sense the effect could suggest the presence of two muscarinic receptors with different sensitivities and functions. In addition, DA, MA and IA preparations, we only observed a response equivalent to low ACh sensitivity $\left(10^{-6}\right.$ to $\left.10^{-3} \mathrm{M}\right)$. All responses were abolished by the blocker Atropine $\left(10^{-5} \mathrm{M}\right)$ suggesting the presence of one type of muscarinic receptor that is sensitive to Atropine (Broughton and Donald, 2005; Jennings and Donald, 2010; Moraga and Urriola-Urriola 2014, 2015).

Muscarinic receptors have been identified in vascular smooth muscle in fish, and Ach- induced contraction has been observed in all the species studied so far (Small et al., 1990; Olson and Villa, 1991; Evans and Gunderson, 1998). This contractile response was found in presence or absence of endothelium (Olson and Villa, 1991; Evans and Gunderson, 1998; Miller and Vanhoutte, 2000; Moraga and Urriola-Urriola 2014, 2015). In mammals, on the other hand, ACh induces vascular smooth muscle relaxation by activation of muscarinic receptors expressed in endothelial cells (Furchgott and Zawadzki, 1980). However, ACh-mediated vasoconstriction suggests that a coupled ACh-COX contraction described in our study in fish is similar to that reported in human hypertension and hypertension rat models (Vanhoutte et al., 2005; Shi et al., 
2008) where there was an endothelium dysfunction because of a lower bioavailability of $\mathrm{NO}$ due to the increase in oxidative stress that stimulates COX and production of prostaglandin vasoconstrictors (Vanhoutte, 2011).

\subsection{Acetylcholine-cyclooxygenase vasoconstriction pathway}

Our results demonstrate that the ACh-mediated vasoconstriction in all the vessels studied (PA, DA, MA and IA) was blocked with At $\left(10^{-5} \mathrm{M}\right)$, indicating the presence of muscarinic receptors that promote vascular vasoconstriction in C. gayi. However, when vessels were blocked by IND $\left(10^{-5} \mathrm{M}\right)$, the high sensitivity ACh-mediated vasoconstriction that was previously described, was practically abolished in all the vessels studied, suggesting a coupling mechanism between activation of muscarinic receptors with the production of vasoconstrictor prostanoids mediated by COX fish to turtle (Miller and Vanhoutte 1986, 2000) and in C. gayi, an effect similar to that previously reported in the marine fish G. laevifrons and I. conceptionis (Moraga and Urriola-Urriola 2014, 2015). This effect did not modify the low sensitivity ACh-mediated vasoconstriction suggesting that this mechanism is mediated by muscarinic receptors in the vascular smooth muscle present in all the vessels studied. In contrast, the low sensitivity ACh-mediated vasoconstriction was abolished in MA and IA. A strategy to corroborate the participation of endothelium in the response described in our study is to perform analyses without endothelium in the presence or absence of ACh plus COX inhibitors. Unfortunately, we did not do this design in our study.

In conclusion, our results show that C.gayi exhibit a similar vasoconstrictor pattern as that observed in marine fish by an ACh-mediated mechanism regulated by muscarinic receptors that activate a cyclooxygenase contraction pathway, and $\mathrm{ACh}$ is not related with relaxing mechanisms. These results suggest that maintenance in the vasoconstrictor mechanism mediated by $\mathrm{ACh} \rightarrow \mathrm{COX}$ $\rightarrow$ vasoconstriction is conserved from fish to frogs.

\section{Acknowledgements}

We are grateful for the technical assistance provided by Mr. Hervis Galleguillos and the students of Medicine Carolina Norero, Daniela Gonzalez, Natalia Soto and Marietta Nuñez who collaborated in the experiments. This research was partially supported by DGIP and Bicentenario project.

\section{References}

BROUGHTON, B.R. and DONALD, J.A., 2005. Nitric oxide control of large veins in the toad Bufo marinus. Journal of Comparative Physiology. B, Biochemical, Systemic, and Environmental Physiology, vol. 175, no. 3, pp. 157-166. PMid:15690177. http:// dx.doi.org/10.1007/s00360-005-0471-7.

CEI, J.M., 1962. Batracios de Chile. Santiago: Ediciones Universidad de Chile, pp. 128.

CLACK, J.A., 2007. Devonian climate change, breathing, and the origin of the tetrapod stem group. Integrative and Comparative
Biology, vol. 47, no. 4, pp. 510-523. PMid:21672860. http:// dx.doi.org/10.1093/icb/icm055.

DUELLMAN, W.E., 2003. Helmeted water toad, Caudiverbera caudiverbera. In M. HUTCHINS, W. E. DUELLMAN and N. SCHLAGER, eds. Grzimek's animal life encyclopedia. Michigan: Gale Group, Farmington Hills, vol. 6, pp. 170

EVANS, D.H. and GUNDERSON, M.P., 1998. A prostaglandin, not NO, mediates endothelium-dependent dilation in ventral aorta of shark (Squalus acanthias). The American Journal of Physiology, vol. 43, no. 4 Pt 2, pp. R1050-R1057. PMid:9575968.

FURCHGOTT, R.F. and ZAWADZKI, J.V., 1980. The obligatory role of the endothelial cells in the relaxation of arterial smooth muscle by acetylcholine. Nature, vol. 288, no. 5789, pp. 373-376. PMid:6253831. http://dx.doi.org/10.1038/288373a0.

GÓMEZ, R.O., BÁEZ, A.M. and MUZZOPAPPA, P., 2011. A new helmeted frog (Anura: Calyptocephalellidae) from an Eocene subtropical lake in northwestern Patagonia, Argentina. Journal of Vertebrate Paleontology, vol. 31, no. 1, pp. 50-59. http://dx.doi. org/10.1080/02724634.2011.539654.

JENNINGS, B.L. and DONALD, J.A., 2010. Mechanisms of nitric oxide-mediated, neurogenic vasodilation in mesenteric resistance arteries of toad Bufo marinus. American Journal of Physiology. Regulatory, Integrative and Comparative Physiology, vol. 298, no. 3, pp. R767-R775. PMid:20071617. http://dx.doi. org/10.1152/ajpregu.00148.2009.

MILLER, V.M. and VANHOUTTE, P.M., 1986. Endotheliumdependent responses in isolated blood vessels of lower vertebrates. Blood Vessels, vol. 23, no. 4-5, pp. 225-235. PMid:3490888.

MILLER, V.M. and VANHOUTTE, P.M., 2000. Prostaglandins but not nitric oxide are endothelium-derived relaxing factors in the trout aorta. Acta Pharmacologica Sinica, vol. 21, no. 10, pp. 871-876. PMid:11501036.

MORAGA, F.A. and URRIOLA-URRIOLA, N., 2014. Vascular function in arteries of intertidal fish Girella laevifrons (Kyphosidae). Brazilian Journal of Biology = Revista Brasileira de Biologia, vol. 74, no. 3, pp. 739-743. PMid:25296227. http://dx.doi. org/10.1590/bjb.2014.0099.

MORAGA, F.A. and URRIOLA-URRIOLA, N., 2015. Acetylcholine produces contraction mediated by cyclooxigenase pathway in arterial vessels in the marine fish (Isacia conceptionis). Brazilian Journal of Biology $=$ Revista Brasileira de Biologia, vol. 75, no. 2, pp. 362-367. PMid:26132019. http://dx.doi.org/10.1590/15196984.13413

MYERS, C.W. and STOTHERS, R.B., 2006. The myth of Hylas revisited: the frog name Hyla and commentary on Specimen medicum (1768) of J.N. Laurenti, the "father of herpetology". Archives of Natural History, vol. 33, no. 2, pp. 241-266. http:// dx.doi.org/10.3366/anh.2006.33.2.241.

OLSON, K.R. and VILLA, J., 1991. Evidence against endotheliumderived relaxing factor(s) in trout vessel. The American Journal of Physiology, vol. 260, no. 29, pp. 925-933.

ROČEK, Z., 2003. Larval development and evolutionary origin of the anuran skull. In H. HEATWOLE, ed. Amphibian biology: osteology. Chipping Norton: Surrey Beatty \& Sons, pp.1878-1995.

SHI, Y., MAN, R. and VANHOUTTE, P.M., 2008. Two isoform of cyclooxygenase contribute to augmented endotheliumdependent contractions in femoral arteries of 1-years-old rats. Acta Pharmacologica Sinica, vol. 29, no. 2, pp. 185-192. PMid:18215347. http://dx.doi.org/10.1111/j.1745-7254.2008.00749.x. 
SMALL, S.A., MACDONALD, C. and FARREL, A.P., 1990. Vascular reactivity on the coronary artery in rainbow trout (Oncorhynchus mykiss). The American Journal of Physiology, vol. 258, no. 6 Pt 2, pp. R1402-R1410. PMid:2360689.

STASSEN, F.R., RAAT, N.J., BROUWERS-CEILER, D.L., FAZZI, G.E., SMITS, J.F. and DE MEY, J.G., 1997. AngiotensinII induces media hypertrophy and hyperreactivity in mesenteric but not epigastric small arteries of the rat. Journal of Vascular Research, vol. 34, no. 4, pp. 289-297. PMid:9256089. http:// dx.doi.org/10.1159/000159236.
VANHOUTTE, P.M., 2011. Endothelium-dependent contractions in hypertension. When Prostacyclin becomes ugly. Hypertension, vol. 57, no. 3, pp. 526-531. PMid:21220708. http://dx.doi. org/10.1161/HYPERTENSIONAHA.110.165100.

VANHOUTTE, P.M., FELETOU, M. and TADDEI, S., 2005. Endothelium-dependent contractions in hypertension. British Journal of Pharmacology, vol. 144, no. 4, pp. 449-458. PMid:15655530. http://dx.doi.org/10.1038/sj.bjp.0706042.

VIDAL, M.A. and LABRA, A., 2008. Herpetología de Chile. Santiago: Science Verlag, pp. 594. 